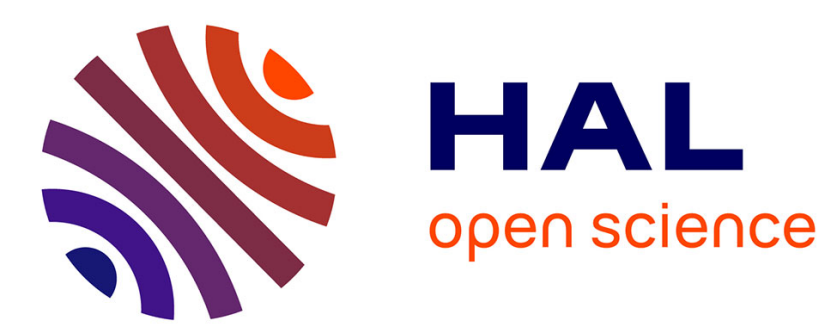

\title{
Why do women's wages increase so slowly throughout their career? A dynamic model of statistical discrimination
}

Nathalie Havet, Catherine Sofer

\section{- To cite this version:}

Nathalie Havet, Catherine Sofer. Why do women's wages increase so slowly throughout their career? A dynamic model of statistical discrimination. 2007. halshs-00193372

\section{HAL Id: halshs-00193372 \\ https://shs.hal.science/halshs-00193372}

Submitted on 3 Dec 2007

HAL is a multi-disciplinary open access archive for the deposit and dissemination of scientific research documents, whether they are published or not. The documents may come from teaching and research institutions in France or abroad, or from public or private research centers.
L'archive ouverte pluridisciplinaire HAL, est destinée au dépôt et à la diffusion de documents scientifiques de niveau recherche, publiés ou non, émanant des établissements d'enseignement et de recherche français ou étrangers, des laboratoires publics ou privés. 
Why do women's wages increase so slowly throughout their career? A dynamic model of statistical discrimination

Nathalie Havet, Catherine Sofer

October 2007

GATE Groupe d'Analyse et de Théorie Économique UMR 5824 du CNRS

93 chemin des Mouilles - 69130 Écully - France

B.P. $167-69131$ Écully Cedex

Tél. +33 (0)4 72866060 - Fax +33 (0)4 72866090

Messagerie électronique gate@gate.cnrs.fr

Serveur Web : www.gate.cnrs.fr 


\title{
WHY DO WOMEN'S WAGES INCREASE SO SLOWLY THROUGHOUT THEIR CAREER? A DYNAMIC MODEL OF STATISTICAL DISCRIMINATION ${ }^{1}$
}

\author{
Nathalie HAVET ${ }^{2}$ \\ University of Lyon, Lyon, F-69003, France; CNRS, UMR 5824, GATE, Ecully, F-69130, \\ France; ENS LSH, Lyon, F-69007, France; Centre Leon Berard, Lyon, F-69003, France \\ Catherine SOFER ${ }^{3}$ \\ Université Paris1-Panthéon-Sorbonne, and Paris School of Economics
}

\begin{abstract}
The aim of this paper is to explain the growing wage differentials between men and women during their working careers. We provide a dynamic model of statistical discrimination, which integrates specific human capital decisions: on-the-job training investment and wages are endogenously determined. We reveal a small wage differential at the beginning of women's career, followed by a larger wage differential; this is partly due to a lower level of human capital investment by women and partly because firms smooth training costs between different periods.

\section{Résumé}

Cet article a pour but d'expliquer le différentiel de salaire croissant entre hommes et femmes durant leur carrière. Nous pouvons un modèle dynamique de discrimination statistique qui incorpore les decisions d'investissement en capital humain spécifique : le montant de l'investissement en formation en enterprise et les salaries sont determines de façon endogène. Nous obtenons un écart de salaire faible en défaveur des femmes en début de carrière, suivi par un différentiel plus important. Ce résultat s'explique d'une part par un faible investissement en capital humain des femmes et d'autre part par le lissage des coûts de formation des entreprises entre les différentes périodes.
\end{abstract}

JEL: J16, J24, J31, J62, J71.

Keywords: Statistical discrimination, careers, male/female differentials, gender wage gap, specific human capital.

Mots clés : discrimination statistique, différences hommes/femmes, écart de salaire, capital humain spécifique.

\footnotetext{
$1 \quad$ Helpful comments by Guy Lacroix, Andrew Clark, Gilbert Colletaz, Lloyd Parquin. Earlier versions of this paper were presented at the European Association of Labor Economists, European Society for Population Economics conference, European Economic Association, Journées de Microéconomie Appliquée. We thank participants in these seminars for their suggestions.

- Nathalie HAVET, GATE, 93, chemin des Mouilles - B.P.167, 69131 Ecully cedex, France. Phone: 33 (0)

4728660 83. Fax: 33(0) 4728660 90. E-mail : havet@gate.cnrs.fr.

$\checkmark \quad$ Catherine SOFER, CES 106-112 Boulevard de l'Hôpital 75013 Paris, France. Phone: (33) 144078258. Fax: (33) 14482 47. E-mail: Catherine.sofer@univ-paris1.fr.
} 


\section{INTRODUCTION}

Economists have proposed a variety of explanations for the differences in wages and occupations between men and women ${ }^{4}$. In the first theories developed in the literature, two opposite strands have dominated: models that relate differences to productivity differentials as human capital theory and theories of discrimination which attribute differences to either employers' prejudices, i.e. « taste discrimination » as explained by Becker (1957), or imperfect information, i.e. « statistical discrimination » initiated by Phelps (1972) and Arrow (1973). However, all of these theories in their earliest and simplest version are not supported by empirical evidence. Human capital theory has not been able to explain the entire gender wage gap ${ }^{5}$. Models based on taste discrimination predict the elimination of the male/female differential in the long run, whereas their persistency has been observed for decades in most OECD countries. Models based on statistical discrimination have proved deceptive since they were unable to generate a gender/racial gap in mean wages.

Consequently, models of second generation have been developed that go beyond the strict opposition between productivity differentials and discrimination. For example, recent models of taste discrimination integrate henceforth the dynamic of job-search costs (Flabbi, 2005; Bowlus and Eckstein, 2002; Rosen, 2003; Black, 1995; Sattinger, 1996 ; Sasaki, 1999) and obtain more interesting conclusions in long term. But these models merely ask the question by looking at one

\footnotetext{
4 For a review of the literature, see Cain (1986) and, more recently, Altonji and Blank (1999) and Havet
} (2004).

5 The empirical papers, from Mincer and Polachek (1974) to more recent works (Light and Ureta, 1995) for example, find that only $50 \%$ of the gender wage gap can be explained by human capital variables alone. 
step back; it does not explain why employers should be prejudiced. By contrast, statistical discrimination is more appealing because it suggests that the gender gap may be a rational response by firms to imperfect information of individual productivity.

More precisely, research in the field of statistical discrimination has followed two different paths. The first one, based on Arrow (1973), examines how a priori statements (true or not) about different groups can influence hiring decisions or wages. Recent models of this kind are, for example, the combination of dynamic job assignment models with human capital assumptions. They explain wage differentials as well as promotions (Lazear and Rosen, 1990; Barron, Black and Loewestein, 1993) and their long term persistency (Coate and Loury, 1993; and more recently Moro and Norman, 2004; Moro, 2003; Fryer, 2006).

The second path followed in the field of statistical discrimination is more directly based on the pioneer work by Phelps (1972). It states that employers are unable to precisely know the productivity of each employee insofar as the signals available to them (recruitment tests, diplomas, etc.) are less reliable for women than for men. Recent work has extended Phelps's seminal contribution - unable to generate a gender/racial gap in mean wages- by introducing human capital investment decisions (Lundberg and Startz, 1983; Lundberg, 1991) or by accounting for job matching (Rothschild and Stiglitz, 1982; Oettinger, 1996). Nonetheless, contrary to the main extensions in the other strands of discrimination, these models are generally static - except for Oettinger (1996). However, we empirically observe a growing male-female wage gap over the course of the worker's career (Loprest, 1992; Lynch, 1992). 
Following this path, the model we propose here combines the theories of human capital and statistical discrimination "à la Phelps" in a dynamic setting. Note that Oettinger (1996), using a dynamic framework, demonstrates that men's and women's wages could have different wage profiles, but a gender wage gap emerges only after a few years of working life, which is not generally verified empirically.

We use the statistical discrimination model of Lundberg and Startz (1983) as our starting point. It incorporates Phelps's basic hypothesis of a difference between the quality of the information yielded by men and women, and explicitly integrates on-the-job training decisions by workers. The underlying idea is that, as women's job skills are less accurately evaluated than those of men, they have less incentive to make productivity-enhancing investments in human capital. Responding to these incentives, women acquire less human capital, and their average productivity and wages are correspondingly lower. However, the key difference between Lundberg and Startz's model and the model developed in this paper is that we assume all on-thejob training to be firm specific (Hashimoto 1981; Kato 1991).

More precisely, as in Lundberg and Startz (1983), human capital investment and wages are endogenously determined ${ }^{6}$. Workers decide their on-the-job training investment themselves by comparing the costs and the expected return to training. However, firm-specific training cannot be used until the end of the training period, which explains the necessity of developing an explicit two-periods statistical discrimination model. The costs and the benefits of the resulting specific human capital (Hashimoto 1981; Kato 1991) are shared between the two periods; as in Kuhn

\footnotetext{
6 This is a traditional assumption in human capital models.
} 
(1993), wages are determined by a smoothing of full training costs, including a type of insurance cost. However, we do not retain Kuhn's assumption of a weaker labor force attachment for women $^{7}$. We explicitly specify training costs, which allows us to derive equilibrium solutions. Consequently, the novelty of our model is that it can explain the male and female wage schedules as well as their average wages in a given period. Although Lundberg and Startz do obtain a gender wage gap in their model, it is deprived of any dynamics: the wage profile is flat and the wage differential is constant. What we determine is the same first period wage differential, but a more realistic increase in wages, a flatter wage profile for women than for men, and thus an increase in the wage differential over time.

We demonstrate that the higher the level of initial or professional training, the larger the resulting wage gap between men and women. This latter result is also more realistic. The basic idea of our model is that firms rationally respond to the greater uncertainty on women's productivity by offering men and women different wage schedules, when rationally smoothing training costs between different periods. As the return to on-the-job training is lower for women, the latter invest less in specific human capital, so that there are also productivity differences by sex. As a result, both the average and the slope of the women's wage profile are lower than men's.

Our model yields several new and testable empirical predictions for statistical discrimination. Our findings are consistent with a substantial body of applied research that has addressed the question

\footnotetext{
$7 \quad$ More precisely, we do not need this assumption in order to obtain the main results of the model; adding an assumption of weaker labor force attachment for women only reinforces our results. See below.
} 
of differences in on-the-job training between men and women. Several studies have also demonstrated, using panel data, that women are less likely to acquire on-the-job training than their male counterparts and that this difference can explain a large part of the gender wage gap (Corcoran and Duncan ,1979; Gronau, 1988; Lynch, 1992; Olsen and Sexton, 1996; Royalty, 1996). In addition, Altonji and Spletzer (1991) reveal that the incidence of training was slightly higher among women than among men, but the amount of training was higher among men. Barron, Black, and Loewenstein's (1993) find that women have a shorter duration of on-the-job training.

The following section presents the structure of our model. We then deduce equilibrium wages and training, before examining their implications for the gender wage gap. Some concluding remarks are presented on the links between empirical evidence and economic policies.

\section{A MODEL OF WAGES AND TRAINING}

Our approach is first based on the model of Lundberg and Startz (1983), modified to include specific human capital. Our contribution is to extend the Lundberg and Startz's model to a dynamic framework in which we can compare the lifetime wage schedules of men and women. The other main extension is that the costs of training are smoothed over the two periods, generating a growing gender wage gap over time.

In our model, the agents are competitive firms who pay wages equal to the expected value of a worker's marginal product, conditional upon all information available to them, and incomemaximizing workers who decide on the size of their human capital investments based on known wage schedules. Workers invest in acquiring human capital to the point where the marginal cost 
of further investment just balances the increment to wages produced by the increased investment. Before we describe the agent's objective functions and determine the equilibrium, it is essential to define the costs of acquired training, its impact on workers' marginal product and to precise the informational context in which firms make their wage decisions.

\subsection{On-the-job training and individual productivity}

As in Kuhn (1993), we assume that worker's tenure with a firm can be split into two subperiods. The newly hired workers start work with a period of on-the-job training - first period -, which is specific to their particular job. Thereafter, in the post-training period - second period -, the workers put their human capital to work at the firm. Individuals have varying levels of innate abilities and acquired skills, which determine their productivity in any employment. The (gross) output per worker in the post-training period is an increasing function of human capital investment, and is denoted $\theta($.$) . Following Lundberg and Startz (1983), we specify a functional$ form for worker's output. For each worker, the latter depends upon both the amount of training received at work, $X_{i}$, and on the worker's general human capital, $a_{i}$ (this latter being a mixture of innate abilities and any training or schooling received prior the labor market entry):

$$
\theta\left(a_{i}, X_{i}\right)=a_{i}+b X_{i}
$$

But the desired level $X_{i}$ of on-the-job training has a cost in terms of foregone output. We imagine that both the total and marginal cost of training rise with the amount of training received: new (productive) knowledge takes more and more time to acquire. In other words, there are diminishing returns to scale in training, which is a standard hypothesis in the human capital literature (see Hashimoto (1981) and Lundberg and Startz (1983), for example). The costs of training are assumed to be quadratic: 


$$
C\left(X_{i}\right)=c^{2} X_{i}^{2} ; \quad C^{\prime}\left(X_{i}\right)=2 c^{2} X_{i}
$$

We assume further that $C\left(X_{i}\right)>1$ and $c<b$. As will appear below, without the latter assumption, it would never be optimal for firms to train workers.

These benefits and costs accrue to the individual, so that net output per worker in the training period is $\theta\left(a_{i}, X_{i}\right)-C\left(X_{i}\right)$. In addition, there are likely to be positive externalities for the firm: worker $i$ 's training may well make her more efficient in passing on knowledge informally to her subordinates and colleagues. Though training i implies a monetary cost of $C\left(X_{i}\right)$, from the firm's point of view, those externalities increase the difference between benefit and cost of $i$ 's training. We suppose that for the firm, the true net output of each trained worker is only $\theta\left(a_{i}, X_{i}\right)-\sqrt{C\left(X_{i}\right)}$, i.e. because of positive externalities, the cost of training for the firm is only $c X_{i}$ rather than $\left(c X_{i}\right)^{2}$. The positive externalities of training hence play the role of a cost reduction at the firm level, that can be seen as an expectation of additional profit. Consequently, the marginal benefit from training for the firm is greater than that for the individual. This assumption could be justified as follows: during their training program, workers are not necessarily replaced, and part of their work is carried out by their colleagues in addition to their usual tasks. This argument is reinforced by the fact that formal training off-site is usually of short duration (Barron, Berger and Black, 1997). The assumption that these two costs (to the worker and to the firm) are different will play an important role in the model below.

Both output per worker $\theta($.$) and training costs C$ (.) are identical for men and women.

Following Kuhn (1993), we compute what can be viewed, from the firm's point of view, as the worker's average net output per period during his/her lifetime in the firm as follows:

$$
\bar{\theta}\left(a_{i}, X_{i}, D^{s}\right)=\underbrace{\left[\theta\left(a_{i}, X_{i}\right)-\sqrt{C\left(X_{i}\right)}\right]}_{\text {First period productivity }}\left(1-D^{s}\right)+\theta\left(a_{i}, X_{i}\right) D^{s}, \quad s \in\{f, m\},
$$


where $D^{s}$ is the relative weight given to the post-training period. $D^{s}$ collects different aspects of the multi-period model: actualization, as usual, but also labor market attachment via the probability of quitting. The more opportunities an individual has outside this particular firm, the less weight will be put on post-training wages, and therefore the lower will be $D^{s}$. In Kuhn (1993), $D^{s}$ is different for men and for women. But, this assumption is not crucial for our results. We shall consider below the possibility of different last-period weights for women and men because of a potential differential in the labor market attachment, but only as an extension of our model. Note that, for simplicity, we also assume that a trained worker instantly reaches her full productivity, so that the difference in net output between the first and the second period derives from training costs only, i.e. $\sqrt{C\left(X_{i}\right)}$ for the firm ${ }^{8}$. Other assumptions could have been done (for example that first period productivity is only a fraction of post training productivity) without notably affecting the results.

Note that $\bar{\theta}$, the worker's average net output per period during his/her lifetime as measured by the firm, is obtained by subtracting from his/her instantaneous productivity, $\theta$, direct costs $\left(\sqrt{C\left(X_{i}\right)}\right)$ but also indirect costs (via $\left.D^{s}\right)$ that can be interpreted as insurance costs against quitting, as will be made clear below.

\footnotetext{
${ }^{8}$ Note that the same assumption is made in Kuhn (1993). Kuhn assumes that outside opportunities com from non labor market work and that demand for non labor market work follows a Poisson process with an exogenous arrival rate of $v^{s}$. All agents are supposed risk-neutral with a discount rate of $\quad r$ and $\lambda$ is a constant, so that $D^{s}=e^{-\left(r+v^{s}\right) \lambda}$
} 


\subsection{Wage Schedules and Smoothing of Training Costs}

After studying the role of human capital investment on individual productivity, we now consider its effects on wages. Following the standard theory of specific human capital (Hashimoto, 1981; Kato, 1991), we make some assumptions about the way the costs and benefits of training are shared between the two periods. Here we shall retain Kuhn's assumptions, although we suggest a different story.

First, the labor market is assumed to be ex ante perfectly competitive, so that firms will design jobs to maximize expected utility of workers, subject to a zero-profit constraint. Put differently, it means that workers will get all of the benefits from the investment in on-the-job training, net of all the costs, including the costs of the risk incurred by the firm when it transfers a fraction of the direct training costs to the second period: as human capital is assumed to be specific, wage schedules are not constrained by productivity schedules. But transferring part of the direct cost is risky, because the worker may quit. Let $\alpha, \alpha \in[0,1]$ characterize the way costs are smoothed intertemporally. More precisely, according to the above interpretation of $\bar{\theta}, \theta-\bar{\theta}$ can be viewed

as the full costs borne by the firms while investing in its workers. Under zero-profit assumption, full benefits, but also full costs, are accruing to the worker: $(1-\alpha)$ stands for the fraction of costs that the worker will bear in the second period, so that the wage of the second period, $w_{2 i}^{s}$ is set as:

$$
\begin{aligned}
& w_{2 i}^{s}=\underbrace{\theta\left(a_{i}, X_{i}\right)}_{\text {worker's productivity }}-\underbrace{(1-\alpha)\left[\theta\left(a_{i}, X_{i}\right)-\bar{\theta}\left(a_{i}, X_{i}, D^{s}\right)\right]}_{\text {fraction of costs that the worker will bear }} . \\
& \Leftrightarrow w_{2 i}^{s}=\alpha \theta\left(a_{i}, X_{i}\right)+(1-\alpha) \bar{\theta}\left(a_{i}, X_{i}, D^{s}\right), s \in\{f, m\}
\end{aligned}
$$

Note that we assume $\alpha$ as exogenous (it can be seen as a parameter): its value will depend on factors such as competitive wages for low-skilled and skilled workers, interest rates, etc... First- 
period wages, $w_{1 i}^{s}$, are determined by the zero-profit condition, which is a consequence of the perfectly competitive markets assumption.

\subsection{Imperfect Information and Individual Productivity}

The last building block is derived from the theory of statistical discrimination - and particularly from Lundberg and Startz (1983). We suppose that firms only have imperfect information regarding the output of individual workers. A worker's output is assumed to depend upon general human capital, $a_{i}$ and investment in on-the-job training, $X_{i}$. However, neither of these variables is directly observed by employers.

With respect to $a_{i}$, the signal of general human capital is typically the level or number of years of education, which are obviously not a perfect indicator of what has been usefully learned. We may, however, imagine that employers have a good idea of the distribution of these general abilities within the labor force, such that $a_{i} \approx N\left(\bar{a}, \sigma_{a}^{2}\right)$.

Uncertainty with respect to $X_{i}$ calls for a little more comment ${ }^{9}$ : why would an employer not know the amount of training received by employees, especially when this is supposed to occur on the job? Mincer (1989) and Barron, Berger and Black (1997) show us why this might be the case: an overwhelming percentage of training within the firm is informal. This is for example, informal co-worker training or "learning by watching". Newly hired workers learn by watching what established workers do. The other part of informal training is "learning by doing", whereby the most efficient manner of doing something is gradually revealed by various different attempts to

\footnotetext{
${ }^{9}$ One important aspect to keep in mind is that in the present model what is uncertain is the amount of training, while in Hashimoto (1981) it is the productivity of training which is subject to noise..
} 
carry out the task in hand. As such, firms may have a less than perfect idea of the amount of training that workers receive. Barron, Black and Loewenstein (1989) estimate that $96 \%$ of on-thejob training in the first three months following recruitment in the United States is informal, and that one-third of this is "learning by watching".

Employers therefore know the distribution of human capital investments, and the output of the average worker, but cannot exactly predict the output of a particular worker as a function of the signals received. Their measure of individual productivity, $T_{i}$, is imperfect:

$$
T_{i}=\left(a_{i}+u_{i}\right)+b\left(X_{i}+v_{i}\right)=\theta\left(a_{i}, X_{i}\right)+\varepsilon_{i},
$$

where $\varepsilon_{i}=u_{i}+b v_{i}$ and $\varepsilon_{i} \approx N\left(\bar{\varepsilon}, \sigma_{\varepsilon}^{2}\right)$.

Thus, part of the error term $\left(u_{i}\right)$ comes from the heterogeneity of the productivity linked to pretraining human capital, and another part $\left(v_{i}\right)$ appears through the training process itself.

We shall assume that $a_{i}$ and $\varepsilon_{i}$ are uncorrelated, though this assumption is not crucial ${ }^{10}$. Moreover, we imagine that the most likely case is that $\bar{\varepsilon}=0$, i.e. $\bar{T}$ is an unbiased predictor of the productivity of the average worker. We also suppose that men and women have the same distribution of general human capital: $\bar{a}^{f}=\bar{a}^{m}$ and $\sigma_{a^{f}}^{2}=\sigma_{a^{h}}^{2}=\sigma_{a}^{2}$.

\footnotetext{
${ }^{10}$ All of our results hold if we allow $a_{i}$ and $\varepsilon_{i}$ to be correlated. This correlation would mean that employers may be better able to predict the productivity of better-qualified workers. It would be the case if education would operate via a process of selection, rendering the highly-qualified more homogeneous in terms of productivity. Consequently, the lack of correlation between measurement errors and worker's qualification implies that productivity measures are reasonably homogeneous within groups of workers.
} 
Last, as in standard models of statistical discrimination (Phelps, 1972 ; Lundberg and Startz,1983; Lundberg, 1991; Oettinger, 1996), we consider that the uncertainty associated with women's productivity is greater than that for men's: $\sigma_{\varepsilon^{f}}^{2}>\sigma_{\varepsilon^{m}}^{2}$. Several justifications to this assumption often made in the literature can be given. The first one is related to cultural differences. For example, Henley (1977) and Lang (1986) point out that men and women differ in their communication style and therefore the evaluation process is subject to greater "error" if the applicant is a woman, given that employers and managers are disproportionately men. In the same spirit, Montgomery (1991) formally shows that the least represented group in the top-level jobs, women typically, has a certain disadvantage in terms of informational quality. Another reason for this inequality could result from women's higher investment in household work (see, for example Goldschmidt-Clermont and Pagnossin-Aligisakis (1995)), which could imply individual constraints. Among others, these constraints have the characteristics of being largely unobservable (by the employer) and of being subject to a high variability from individual to individual. Finally, on the job training has both formal and informal components. As discussed above, the informal component of training is likely more difficult to measure accurately than its informal counterpart. It is possible that employers take expected women's greater investment in household work into account and consequently propose less formal training, especially if formal training implies traveling to another place or taking night courses. Since women are offered less formal training, their share of informal training is higher. As a direct consequence, women's productivity will be more difficult to measure than that of men.

We will now use the above model to determine equilibrium wages and training, and to analyze the difference in the results between men and women. 


\section{EQUILIBRIUM}

General human capital (innate abilities and schooling) is considered to be exogenous in our model. On the other hand, the demand for training by workers will depend on its expected labor market return compared to its cost. The return to training will differ by sex, as a direct result of the asymmetric information described above. In consequence, the demand for training will differ by sex, as will both average productivity and average wages. Let us first turn to the equilibrium determination.

\subsection{Equilibrium Determination}

Equilibrium results from optimizing behaviour by both firms and workers. Firms are competitive, negotiating worker compensation on an individual basis. They will offer wages equal to individual expected productivity conditional on the individual signal due to the binding

zero expected profits: $w_{2 i}^{s}=E\left[\alpha \theta\left(a_{i}, X_{i}\right)+(1-\alpha) \bar{\theta}\left(a_{i}, X_{i}, D^{s}\right) \mid T_{i}\right]$ and $w_{1 i}^{s}$ satisfies $E\left(\Pi \mid T_{i}\right)=0$. Workers know both the costs and the benefits of training (the parameters $b$ and $c$ are common knowledge), and maximize net income. They look at wage offers to determine their optimal level of on-the-job training. Indeed, imperfect information is asymmetric as it only applies to firms. Workers know with certainty the wage schedules offered by firms for their general human capital and their productivity signal. They will invest in specific human capital up to the point at which its marginal cost is just equal to the marginal increase in expected income.

In this set-up, there is linear rational expectations equilibrium for both wages and human capital investments. We obtain explicit solutions by writing the optimal investment in training as a linear function of the worker's characteristics $\left(X_{i}=\rho_{0}+\rho_{a} a_{i}+\rho_{\varepsilon}^{s} \varepsilon_{i}\right)$, technique suggested by 
Lundberg and Startz (1983). The equilibrium is fully determined by the three following equations $^{11}$ :

$$
\begin{gathered}
w_{1 i}^{s}=\bar{T}^{s}-\bar{\varepsilon}-\left[\left(1-D^{s}\right)+\alpha D^{s}\right] \frac{c}{b}\left[\bar{T}^{s}-\bar{\varepsilon}-\bar{a}\right]+\beta_{\varepsilon}^{s}\left(T_{i}-\bar{T}^{s}\right), s \in\{f, m\}, \\
w_{2 i}^{s}=\bar{T}^{s}-\bar{\varepsilon}-(1-\alpha)\left(1-D^{s}\right) \frac{c}{b}\left[\bar{T}^{s}-\bar{\varepsilon}-\bar{a}\right]+\beta_{\varepsilon}^{s}\left(T_{i}-\bar{T}^{s}\right), s \in\{f, m\}, \\
X_{i}^{s}=\beta_{\varepsilon}^{s} \frac{b}{2 c^{2}}, s \in\{f, m\}
\end{gathered}
$$

$\beta_{\varepsilon}^{s}$ only depends on the relative sizes of the variances of general human capital and the measurement errors with respect to productivity $^{12}$; it is bounded between zero and one and can been viewed as the ratio of private to social marginal returns to on-the-job training. The optimal level of on-the-job training then increases with its relative profitability $\left(b / 2 c^{2}\right)$ and wages in both periods are an increasing function of the individual productivity signal.

\subsection{Interpretation of the results}

Each worker has a basic wage reflecting the productivity of the "average worker", with a second term (positive or negative) according to whether his/her productivity is thought to be greater or less than the average respectively. The wages equations can be rewritten as:

\footnotetext{
${ }^{11}$ See the proof in Appendix 1

${ }^{12}$ The same would hold if a and $\varepsilon$ were allowed to be correlated, under the assumption that $\sigma_{\varepsilon a}$ is small compared to $\sigma_{a}^{2}$ and $\sigma_{\varepsilon}^{2}$
} 


$$
\begin{aligned}
& w_{1 i}^{s}=\underbrace{(1-\alpha) \bar{P} \bar{M}^{s}+\alpha \bar{P} \bar{M}_{1}^{s}}_{\text {First period basic wage }}+\beta_{\varepsilon}^{s}\left(T_{i}-\bar{T}^{s}\right), s \in\{f, m\}, \\
& w_{2 i}^{s}=\underbrace{(1-\alpha) \bar{P} \bar{M}^{s}+\alpha \bar{P} \bar{M}_{2}^{s}}_{\text {Second period basic wage }}+\beta_{\varepsilon}^{s}\left(T_{i}-\bar{T}^{s}\right), s \in\{f, m\},
\end{aligned}
$$

where $\bar{P}^{s}$ is the worker's expected average net output per period and $\quad \bar{P} \bar{M}_{t}^{s}$, the average expected instantaneous output of type $s$ workers on the period $t$ [see appendix 2].

Each period basic wage depends on an average of intertemporal productivity and of instantaneous productivity, weighted with the same parameter $\alpha$, which characterizes the way training costs are smoothed intertemporally. This is the part of wages based upon group characteristics. The second part of the wages depends on individual signals. We therefore rediscover here one of the key ideas of previous statistical discrimination models (Phelps, 1972; Lundberg and Startz, 1983): the individual wages are a weighted average of the group mean and individual signals. Graphically, wages in the two periods can be represented as in Figure I, as functions of the individual productivity signals.

Between the training and the post-training period, workers enjoy a rise in wages, which is independent of their measured productivity:

$$
w_{2 i}^{s}-w_{1 i}^{s}=\alpha \frac{c}{b}\left[\bar{T}^{s}-\bar{\varepsilon}-\bar{a}\right]=\alpha c \bar{X}^{s} .
$$

\subsection{Special Cases}

We shall look here at three interesting cases.

$$
\text { 3.3.1. } \alpha=0 \text { and } D^{s}=1
$$

These assumptions correspond to Lundberg and Startz's model (1983), which can been viewed as a special case of our model in which the training costs are not smoothed intertemporally 
( $\alpha=0)$ and where the withdrawal rate from the labor market is zero (it implies $\quad D^{s}=1$, i.e. all weight is given to the post-training period ${ }^{13}$ ). Indeed, under these assumptions, the wages in the two periods are identical and have the same expression as in Lundberg and Startz's static framework: $w_{i}=\bar{T}^{s}-\bar{\varepsilon}+\beta_{\varepsilon}^{s}\left(T_{i}-\bar{T}^{s}\right)$. Consequently, the wage profile is flat.

\subsection{2. $\alpha=0$ and $D^{s} \neq 1$}

If we take into account the worker's job attachment $\left(\quad D^{s} \neq 1\right)$ without the assumption of intertemporal cost smoothing $(\alpha=0)$, the wages are identical at the two periods. Compared to the Lundberg and Startz's model, the resulting wage expressions would also include an additional term for training costs, but the wage profile would remain flat.

\subsection{3. $\alpha \neq 0$ and $D^{s}=1$}

Compared to Lundberg and Startz (1983), the only new assumption here is the costs smoothing over two periods $(\alpha \neq 0)$, keeping a zero withdrawal rate from the labor market $\left(D^{s}=1\right)$. In that case, the results show an increasing wage profile, equal to $\alpha c \bar{X}^{s}$. In our model, $\alpha \neq 0$ is also a crucial assumption to obtain a dynamic framework.

We will now use the above expressions of the equilibrium to examine the question of malefemale wage gaps.

\section{IMPLICATIONS FOR GENDER DIFFERENCES IN THE LABOR MARKET}

According to our model, women's less accurate productivity signals (see above, p. 12) will generate gender wage differences. Here $\sigma_{\varepsilon^{f}}^{2}>\sigma_{\varepsilon^{m}}^{2}$, which implies $\beta_{\varepsilon}^{f}<\beta_{\varepsilon}^{m}$.

\footnotetext{
${ }^{13}$ See footnote 8 .
} 
Let us first assume here, for the sake of simplicity, that men's and women's attachment to the labor market is the same: $D^{f}=D^{m}=D^{s}$.

We shall first look at the implications of these two assumptions, i.e. the impact of statistical discrimination alone and then extend the results by relaxing the latter assumption above, thus taking into account a gender differential in labor market attachment.

\subsection{Predictions with statistical discrimination alone}

Applying the assumption and $\beta_{\varepsilon}^{f}<\beta_{\varepsilon}^{m}$ to equations (6) and (7), it is immediately clear that firms will rationally discriminate between men and women by offering them separate wage schedules. In particular, firms pay less attention to individual productivity signals when setting women's wages due to the imprecision of the former. They give more weight to average group measures relative to individual information, to avoid damaging erroneous inferences about individual productivity. Women's wage schedules are therefore flatter than those offered to men $\left(\beta_{\varepsilon}^{f}<\beta_{\varepsilon}^{m}\right)$ and women's wages are more tightly distributed around the basic wage (that is, the wage received by the average individual in the group). The variance of wages over the two periods is given by $\sigma_{w^{s}}^{2}=\beta_{\varepsilon}^{s} \sigma_{a}^{2}$. As $\beta_{\varepsilon}^{m}>\beta_{\varepsilon}^{f}$, we see that male wages have greater variance than female wages.

The wage schedules reveal that the greater is the error related to the measurement of human capital investment, the lower is the expected return from this investment. Decisions being partly based on expected returns, it is obvious that men and women will not adopt the same optimal training strategies. Equation (8) shows that men invest more in on-the-job training than do women. Men acquire, on average, $\bar{X}^{m}-\bar{X}^{f}=\left(\beta_{\varepsilon}^{m}-\beta_{\varepsilon}^{f}\right) b /\left(2 c^{2}\right)$ of additional training compared to women, since the marginal return to each unit of on-the-job training, $X$, is higher. Intuitively, 
firms have more trouble in evaluating women's productivity, hence human capital investments by women are less likely to be recognized and rewarded. This being so, women have less incentive to invest in human capital in the hope of receiving a higher wage.

Women's lower level of on-the-job training reduces their average intertemporal productivity compared to men:

$$
P \bar{M}^{s}=\mathrm{E}\left[\bar{\theta}\left(a_{i}, X_{i}, D^{s}\right)\right]=\theta\left(\bar{a}, \bar{X}^{s}\right)-\left(1-D^{s}\right) c \bar{X}^{s}=\bar{a}+\bar{X}^{s}\left[b-\left(1-D^{s}\right) c\right], s \in\{f, m\} .
$$

As $\bar{X}^{f}<\bar{X}^{m}$, it is obvious that $P \bar{M}^{f}<P \bar{M}^{m}$. This sex gap in average productivity is coupled with a gender wage gap. Contrary to the original models of statistical discrimination (Phelps 1972), our model predicts a gap in average wages between men and women over the two periods:

$$
\begin{aligned}
& \bar{w}_{1}^{m}-\bar{w}_{1}^{f}=\left(\bar{X}^{m}-\bar{X}^{f}\right)\left[(b-c)+c(1-\alpha) D^{s}\right]>0, \\
& \bar{w}_{2}^{m}-\bar{w}_{2}^{f}=\left(\bar{X}^{m}-\bar{X}^{f}\right)\left[b-c(1-\alpha)\left(1-D^{s}\right)\right]>0 .
\end{aligned}
$$

Men, whose individual productivity signals are more reliable, choose more training and enjoy higher wages.

Equation (11) shows that the average gender wage gap increases from the training to the posttraining periods, with the rise in the wage gap being proportional to the difference in on-the-job training and more precisely equaling to $\alpha c\left(\bar{X}^{m}-\bar{X}^{f}\right)$. The wage gap will then increase more, the more women are discouraged from training (the larger the difference $\left(\bar{X}^{m}-\bar{X}^{f}\right)$ ), the larger the training costs borne by the firm ( $\alpha$ larger), the higher the training costs ( $c$ higher).

In conclusion, women have lower average wages when they enter the labor market, and their subsequent wages increase more slowly than do men's. In particular, women's second-period wages are dragged down by their lower level of investment in on-the-job training. 
Wage schedules of both sexes in the training and post-training periods are shown in Figure II. This figure shows that the gender wage gap is larger than that which would be implied by differences in training only. For the same productivity signal, $T_{i}$, men generally receive higher lifetime wages than do women, except at very low levels of education. Nevertheless, low qualified men catch up their wage disadvantage during their career with respect to female counterparts, since they have a higher wage growth. Indeed, we can see that for all productivity signals $T_{i}$, the gender wage gap increases between the two periods ${ }^{14}$. In addition, the higher is the productivity signal, the greater is the gender wage gap. Our model thus shows that gender wage gaps will be larger amongst the higher-educated groups for the two periods.

If we interpret wage levels as different jobs in the hierarchy - since employers consider workers career profiles when setting wages-, then such gender discrepancies may lead to job segregation: women workers are less likely than their male counterparts to find themselves at the top of the promotion ladder. In other words, women have to present higher quality productivity signals than men in order to be hired or to be promoted to a given position. Interpreted this way, we obtain the same conclusions as Lazear and Rosen (1990) with their dynamic job assignment model "à la Arrow".

In each period, the gender wage gap can be decomposed into two elements:

- that resulting from productivity differences, as the two groups have different levels of onthe-job training.

\footnotetext{
${ }^{14}$ For a given $T_{i}$, we have $\left(w_{2 i}^{m}-w_{2 i}^{f}\right)-\left(w_{1 i}^{m}-w_{1 i}^{f}\right)>0$.
} 
- that due to different wage schedules, corresponding to differences in the way in which similar worker characteristics are rewarded (schooling and on-the-job training).

Although the traditional assumption of a less reliable measure of productivity for women alone drives all of our general predictions, we obtain new results compared to the existing literature. Some previous models predict a wage gap resulting from statistical discrimination (Lundberg and Startz, 1983, for example) or a flatter wage profile resulting from a lower investment in human capital (Kuhn, 1993, for example). Nonetheless, no model of statistical discrimination so far could predict at the same time an initial wage gap, which here keeps growing during the work career, and which is increasing with the initial level of education. Note that, empirically, though counter-examples can be found (see, for example, the U.S. case, Vanneman, 2006) this is the case in most countries where the study has been run. This is true for France, where, as well as in Denmark, the Netherlands, Finland and Germany, the wage gap is higher among the highly educated group. This is consistent with some recent analyses from Denmark and Sweden" (Barth, Røed and Torp, 2002), and for Finland (Napari, 2006):

\subsection{Statistical Discrimination and gender differential in labor market attachment}

It can intuitively be more realistic to assume, as in Kuhn (1993), that female attachment to the labor market is lower than that of males, which implies: $D^{f}<D^{m}$.

In that case, equations (13) and (14) become:

$$
\begin{aligned}
& \bar{w}_{1}^{m}-\bar{w}_{1}^{f}=\left(\bar{X}^{m}-\bar{X}^{f}\right)(b-c)+c(1-\alpha)\left[\bar{X}^{m} D^{m}-\bar{X}^{f} D^{f}\right], \\
& \bar{w}_{2}^{m}-\bar{w}_{2}^{f}=\left(\bar{X}^{m}-\bar{X}^{f}\right)[b-c(1-\alpha)]+c(1-\alpha)\left[\bar{X}^{m} D^{m}-\bar{X}^{f} D^{f}\right] .
\end{aligned}
$$


It can be seen immediately that the new assumption reinforces the previous results: the wage gap become larger at both periods. Comparing with the results obtained when labor market attachment is the same for both genders, the widening of the wage gap is increasing with training $\operatorname{costs} c$, and with the fraction of the costs transferred to the second period $(1-\alpha)$. Women's weaker attachment to the labor market only reinforces the difference in intertemporal productivity and hence similarly increases the gender wage gap at the two periods.

\section{CONCLUSION}

This paper presents a model of growing wage differentials between men and women over their working careers, in the spirit of previous models of statistical discrimination. As usual, the gender disparities come from a difference in the reliability of the productivity measures. The novelty of our model is to introduce an intertemporal smoothing of training costs. The followed dynamic framework allows obtaining more complete predictions.

Our theoretical results are in accordance with most of the empirical findings discussed in the literature. Especially, the key predictions of our model are the following. Firstly men's and women's wage schedules are different: at a given level of productive ability (as measured by onthe-job training and general human capital), men receive higher wages. Note that men have higher average wages than women in both training and post-training periods. Then, as the return to on-the-job training is lower for women, they have less incentive to undertake it. Women will thus acquire less on-the-job training than men. As a consequence, women will have on average a lower intertemporal productivity. Compared to Lundberg and Startz (1983), the main new results 
are due to the dynamic framework of our model: as women's wages grow at a slower rate than men's, the gap between male and female wages increases with time. Our model yields another realistic prediction: the gender wage gap will be higher for the better-educated groups at the two periods. Finally if, when setting wages, employers consider workers career profiles, women workers are less likely than their male counterparts to find themselves at the top of the promotion ladder. In other words, hiring and promotion selection criteria are more severe for women than for men: women have to present higher quality productivity signals than men in order to obtain the same wage or an equivalent job. All these results are consistent with the broad stylized features of the labor market, emphasized in the empirical literature.

For the sake of simplicity, we treat women's labor force attachment as exogenous. A complete analysis would have to take into account the interdependence between the wages offered by employers, women's labor force attachment and their investment in on-the-job training. We can imagine that lower wages and a smaller human capital level give women a greater incentive to quit their job (or at least to reduce working time) when, for example they have to search for child care. Employers' prior beliefs that women are prone to a higher turnover may therefore be selffulfilling, causing long-term persistent gender disparities in the labor market. Investigation of this question is therefore an important topic for future research.

Moreover, our model assumes the existence of a cost-smoothing rule also treated as exogenous. However, how to make this rule endogenous would be an interesting extension. For example, it would be a function of time preference of the employee, situation on the labour market, etc.

This kind of extension would probably allow to relax our implicit assumption of a not genderspecific smoothing rule and improve our results on the gender wage gap. 
Another topic for future research is an empirical test of our model. It would imply the use of individual panel data containing available information about the entire formal and informal onthe-job training, proposed by the firms and accepted by the workers.

Finally, according to our model, several economic policies can be advocated in order to reduce the gender wage gap. We shall concentrate here upon one of them, which are not intuitively obvious: firms should be encouraged to propose rather formal than informal training to their employees. Formal training can be thought as providing a more precise productivity signal than informal training, thus limiting the gender difference in signal reliability. 


\section{APPENDIX 1}

\section{Equilibrium solution}

\section{Employer Behavior}

The firm's problem is to choose male and female wage schedules given the individual productivity measure, $T_{i}$. Second-period wages are given by:

$$
w_{2 i}^{s}=E\left[\alpha \theta\left(a_{i}, X_{i}\right)+(1-\alpha) \bar{\theta}\left(a_{i}, X_{i}, D^{s}\right) \mid T_{i}\right],
$$

which becomes, using the definition of the worker's expected net value of his/her lifetime productivity (equation (3)) and the equations (5) and (1) :

$$
w_{2 i}^{s}=T_{i}-\mathrm{E}\left(\varepsilon_{i} \mid T_{i}\right)-(1-\alpha) .\left(1-D^{s}\right) . c \cdot \mathrm{E}\left(\frac{T_{i}-a_{i}-\varepsilon_{i}}{b} \mid T_{i}\right) .
$$

Since the productivity measure, $T_{i}$, is a linear function of normal random variables, the productivity measure itself is normally distributed with mean $\overline{\mathrm{T}}^{\sigma}=\beta \rho_{0}+\left(1+\rho_{\alpha}\right) \bar{\alpha}+\left(1+\rho_{\varepsilon^{\sigma}}\right) \bar{\varepsilon}$ and variance $\sigma_{T^{s}}^{2}=\left(1+b \rho_{a}\right)^{2} \sigma_{a}^{2}+\left(1+b \rho_{\varepsilon^{s}}\right)^{2} \sigma_{\varepsilon^{s}}^{2}$. In addition, $\left(\mathrm{T}_{1}, \varepsilon_{1}\right)$ have a bivariate normal distribution with correlation coefficient $\left(1+b \rho_{\varepsilon^{s}}\right) \sigma_{\varepsilon^{s}}^{2} / \sigma_{T^{s}}^{2}$, denoted $\left(1-\beta_{\varepsilon}^{s}\right)$, and $\left(T_{i}, a_{i}\right)$ have a bivariate normal distribution with correlation coefficient $\left(1+b \rho_{a}\right) \sigma_{a}^{2} / \sigma_{T^{s}}^{2}$, denoted $\left(1-\beta_{a}^{s}\right)$. We use those properties to compute the conditional expectations ${ }^{15}$ of the equation (A1.3), and we obtain:

\footnotetext{
${ }^{15}$ For example, see Greene (1997, p. 90).
} 


$$
w_{2 i}^{s}=\bar{T}^{s}-\bar{\varepsilon}+\beta_{\varepsilon}^{s}\left(T_{i}-\bar{T}^{s}\right)-(1-\alpha) .\left(1-D^{s}\right) \frac{c}{b}\left[\bar{T}^{s}-\bar{a}-\bar{\varepsilon}+\left(\beta_{a}^{s}+\beta_{\varepsilon}^{s}-1\right)\left(T_{i}-\bar{T}^{s}\right)\right] .
$$

We will see below that this formula can be expressed as a function of average productivity and of the costs of training accruing to the average worker, plus a term reflecting the individual productivity signal. We can go a little further, to get a few mathematical simplifications.

First-period wages are obtained from the zero-profit condition. Expected profit per worker, conditional on all available information, is given by:

$$
\mathrm{E}\left(\pi \mid T_{i}\right)=\mathrm{E}\left[\bar{\theta}\left(a_{i}, X_{i}, D^{s}\right)-\left(1-D^{s}\right) w_{1 i}^{s}-D^{s} w_{2 i}^{s} \mid T_{i}\right]
$$

Using the definition of worker's expected net value of his/her lifetime productivity and replacing second-period wages by the expression (A1.3), in the zero-profit condition, we obtain the explicit expression for the first-period wages:

$$
w_{1 i}^{s}=\bar{T}^{s}-\bar{\varepsilon}+\beta_{\varepsilon}^{s}\left(T_{i}-\bar{T}^{s}\right)-\left[1-(1-\alpha) D^{s}\right] \cdot \frac{c}{b} \cdot\left[\bar{T}^{s}-\bar{\varepsilon}-\bar{a}+\left(\beta_{a}^{s}+\beta_{\varepsilon}^{s}-1\right)\left(T_{i}-\bar{T}^{s}\right)\right] .
$$

\section{Worker Behavior}

Imperfect information is asymmetric as it only applies to firms. Workers know with certainty the wage schedules (equations (A1.3) and (A1.5)) offered by firms. They will invest in specific human capital up to the point at which its marginal cost is just equal to the marginal increase in expected income. 
Expected income itself depends on the wages that the worker receives over his/her entire career: $R_{p i}^{s}=\left(1-D^{s}\right) w_{1 i}^{s}+D^{s} w_{2 i}^{s}$. The optimal investment in human capital implies therefore that $\partial R_{p i}^{s} / \partial X_{i}^{s}=C^{\prime}\left(X_{i}^{s}\right)$, which yields:

$$
X_{i}^{s}=\frac{\beta_{\varepsilon}^{s} b-\left(1-D^{s}\right) \cdot c \cdot\left(\beta_{a}^{s}+\beta_{\varepsilon}^{s}-1\right)}{2 c^{2}}
$$

Since the marginal cost and marginal returns to each unit of training $X$ are identical across workers of the same sex, $X$ is non-stochastic in equilibrium, which implies that $\rho_{a}$ and $\rho_{\varepsilon}^{s}$ are identically zero. The $\beta$ parameters are then given by $\beta_{\varepsilon}^{s}=\sigma_{a}^{2}\left[\sigma_{a}^{2}+\sigma_{\varepsilon^{s}}^{2}\right]$ and $\beta_{\varepsilon}^{s}+\beta_{a}^{s}-1=0$.

\section{Equilibrium Determination}

Last, the expressions for wages and optimal training investment can be simplified and the equilibrium is consequently characterised by the three following equations:

$$
\begin{aligned}
& w_{1 i}^{s}=\bar{T}^{s}-\bar{\varepsilon}-\left[\left(1-D^{s}\right)+\alpha D^{s}\right] \frac{c}{b}\left[\bar{T}^{s}-\bar{\varepsilon}-\bar{a}\right]+\beta_{\varepsilon}^{s}\left(T_{i}-\bar{T}^{s}\right), s \in\{f, m\}, \\
& w_{2 i}^{s}=\bar{T}^{s}-\bar{\varepsilon}-(1-\alpha)\left(1-D^{s}\right) \frac{c}{b}\left[\bar{T}^{s}-\bar{\varepsilon}-\bar{a}\right]+\beta_{\varepsilon}^{s}\left(T_{i}-\bar{T}^{s}\right), s \in\{f, m\},
\end{aligned}
$$

$$
X_{i}^{s}=\beta_{\varepsilon}^{s} \frac{b}{2 c^{2}}, s \in\{f, m\}
$$




\section{APPENDIX 2}

Average expected productivity of type $s$ workers on respectively the first and the second period are given by:

$$
\begin{gathered}
\bar{P} \bar{M}_{1}^{s}=\mathrm{E}\left[\theta\left(\mathrm{a}_{\mathrm{i}}, X_{i}\right)-\sqrt{C\left(X_{i}\right)}\right]=\mathrm{E}\left[\mathrm{T}_{\mathrm{i}}-\varepsilon_{i}-c X_{i}\right]=\bar{T}^{s}-\bar{\varepsilon}-\frac{c}{b}\left[\bar{T}^{s}-\bar{\varepsilon}-\bar{a}\right], \\
\bar{P} \bar{M}_{2}^{s}=\mathrm{E}\left[\theta\left(\mathrm{a}_{\mathrm{i}}, X_{i}\right)\right]=\bar{T}^{s}-\bar{\varepsilon},
\end{gathered}
$$

and the average intertemporal productivity is:

$$
P \bar{M}^{s}=\mathrm{E}\left[\bar{\theta}\left(a_{i}, X_{i}, D^{s}\right)\right]=\bar{T}^{s}-\bar{\varepsilon}-\left(1-D^{s}\right) \frac{c}{b}\left[\bar{T}^{s}-\bar{\varepsilon}-\bar{a}\right], s \in\{f, m\} .
$$

The wage equations $[(\mathrm{A} 1.7)$ and (A1.8)] can therefore be rewritten as:

$$
\begin{aligned}
& w_{1 i}^{s}=\underbrace{(1-\alpha) \bar{P} \bar{M}^{s}+\alpha \bar{P} \bar{M}_{1}^{s}}_{\text {First period basic wage }}+\beta_{\varepsilon}^{s}\left(T_{i}-\bar{T}^{s}\right), s \in\{f, m\}, \\
& w_{2 i}^{s}=\underbrace{(1-\alpha) \bar{P} \bar{M}^{s}+\alpha \bar{P} \bar{M}_{2}^{s}}_{\text {Second period basic wage }}+\beta_{\varepsilon}^{s}\left(T_{i}-\bar{T}^{s}\right), s \in\{f, m\} .
\end{aligned}
$$

\section{REFERENCES}

Altonji J. and Blank R. (1999) "Race and Gender in the Labor Market”, in Handbook of Labor Economics, Ashenfelter O. and Card D., eds. (Vol.3C, Elsevier Science, North-Holland): 3143-3529. 
Altonji J. and Spletzer J. (1991) "Worker Characteristics, Job Characteristics, and the Receipt of On-the-Job Training", Industrial and Labor Relations Review 45(1): 58-79.

Arrow K. (1973) "The Theory of Discrimination", in Discrimination in Labor Markets, Ashenfelter O. and Rees A., eds., Princeton University Press:3-33.

Barron J., Berger M. and Black D. (1997) “How Well Do We Measure Training?”, Journal of Labor Economics 15 (3): 507-528.

Barron J., Black D., and Loewenstein M. (1989) "Job Matching and On-the-Job Training”, Journal of Labor Economics 7 (1): 1-19.

Barron J., Black D. and Loewenstein M. (1993) “Gender Differences in Training, Capital, and Wages", Journal of Human Resources 28 (2): 343-364.

Barth, E., Røed, M. and Torp, H (2002) “Towards a Closing of the Gender Pay Gap", European Commission Report, Oslo.

Becker G. (1957) The Economics of Discrimination, The University of Chicago Press Economics.

Black D. (1995) "Discrimination in a Equilibrium Search Model”, Journal of Labor Economics 13(2): 309-334.

Bowlus A. and Eckstein Z. (2002) "Discrimination and Skill Differences in an Equilibrium Search Model", International Economic Review 43(4): 1309-1345.

Cain G. (1986) “The Economic Analysis of Labor Market Discrimination: A Survey”, in Handbook of Labor Economics, Orley Ashenfelter and Richard Layard, eds. (Vol.1, Elsevier Publishing Company): 693-785.

Coate S. and Loury G.C. (1993) "Will Affirmative-Action Policies Eliminate Negative Stereotypes?", American Economic Review 83(5): 1220-1240. 
Corcoran M. and Duncan G. (1979) "Work History, Labor Force Attachment, and Earnings Differences Between the Races and Sexes", Journal of Human Resources 14 (1): 3-20.

Flabbi L. (2005) "Gender Discrimination Estimation in a Search Model with Matching and Bargaining", IZA Discussion Paper 1764, September.

Fryer R. (2006) "Belief Flipping in a Dynamic Model of Statistical Discrimination", NBER Working Paper $n^{\circ}$ W12174, April.

Goldschmidt-Clermont L. and Pagnossin-Aligisakis E. (1995) "Measures of unrecorded economic activities in fourteen countries" UNDP,Background Papers for the Human Development Report, New York: Oxford UP: 105-155.

Greene W. (1997) Econometric Analysis, 3rd ed., Upper Saddle River, N.J.: Prentice Hall.

Gronau R. (1988) “Sex-related Wage Differentials and Women's Interrupted Labor Careers- the Chicken or the Egg?", Journal of Labor Economics 6(3): 227-301.

Hashimoto M. (1981) "Firm-Specific Human Capital as a Shared Investment", American Economic Review 71(3): 475-82.

Havet N. (2004) "Ecarts salariaux et disparités professionnelles entre sexes : développement théoriques et validité empirique", L'Actualité Economique 80(1): 5-39.

Henley N. (1977) Body Politics : Power, Sex and Nonverbal Communication, N-J :Prentice-Hall.

Kato T. (1991) "Specific Human Capital and Worker Transfers as an Alternative to Layoffs: Theory and Evidence", Ricerche Economiche 45(2-3): 397-420.

Kuhn P. (1993) “Demographic Groups and Personnel Policy”, Labour Economics 1(1): 49-70.

Lang K. (1986) “Language Theory of Discrimination”, Quaterly Journal of Economics 101(2): 363-382. 
Lazear E. and Rosen S. (1990) "Male-female Wage Differentials in Job Ladders", Journal of Labor Economics 8(1): S106-S123.

Light A. and Ureta M. (1995) "Early-Career Work Experience and Gender Wage Differentials", Journal of Labor Economics 13 (1): 121-54.

Loprest P. (1992) "Gender Differences in Wage Growth and Job Mobility", American Economic Review 82(2): 526-532.

Lundberg S. (1991) “The Enforcement of Equal Opportunity Laws Under Imperfect Information: Affirmative Action and Alternatives", Quarterly Journal of Economics 106(1): 309-326.

Lundberg S. and Starzt R. (1983) "Private Discrimination and Social Intervention in Competitive Labor Market", American Economic Review 73(3): 340-347.

Lynch L. (1992) "Private Sector Training and the Earnings of Young Workers", American Economic Review 82(1): 299-312.

Mincer J. (1989) "Job Training: Costs, Returns, and Wage Profiles", National Bureau of Economic Research Working Paper 3208.

Mincer J. and Polachek S. (1974) "Family Investments in Human Capital: Earnings of Women", Journal of Political Economy 82(2): 331-344.

Montgomery J. (1991) "Social Networks and Labour Market Outcomes: Towards and Economic Analysis", American Economic Review 81(5): 1408-1418.

Moro A.(2003) "The Effect of Statistical Discrimination on Black-White Wage Differentials: Estimating a Model with Multiple Equilibrium", International Economic Review 44(2): 467500.

Moro A. and Norman P. (2004) "General Equilibrium Model of Statistical Discrimination", 
Journal of Economic Theory 114(1): 1-30.

Napari, Sami (2006) “The Early Career Gender Wage Gap”, CEP Discussion Paper n 738.

Oettinger G. (1996) "Statistical Discrimination and the Early Career Evolution of the BlackWhite Wage Gap", Journal of Labor Economics 14(1): 52-78.

Olsen R. N. and Sexton E. (1996) "Gender Differences in the Returns to and the Acquisition of On-the-Job Training”, Industrial Relations 35(1): 59-77.

Phelps E. (1972) “The Statistical Theory of Racism and Sexism”, American Economic Review 62 (4): 659-61.

Rosen A. (2003) "Search, Bargaining and Employer Discrimination", Journal of Labor Economics 21(4): 807-829.

Rothschild M. and Stiglitz J. (1982) “A Model of Employment Outcomes Illustrating th Effect of the Structure of Information on the Level and Distribution of Income”, Economics Letters 10:231-236.

Royalty A. B. (1996) "The Effects of Job Turnover on the Training of Men and Women", Industrial and Labor Relations Review 49(3): 506-521.

Sasaki,M. (1999) "An Equilibrium Search Model with Coworker Discrimination", Journal of Labor Economics 17(2): 377-407.

Satinger M. (1996) "Search and Discrimination", Labour Economics 3(2): 143-167.

Vanemann, R. (2006) “End of the Gender Revolution?”, University of Maryland, http://www.bsos.umd.edu/socy/vanneman/endofgr/cpswageeduc.html 


\section{FIGURE I: EQUILIBRIUM WAGE SCHEDULES}

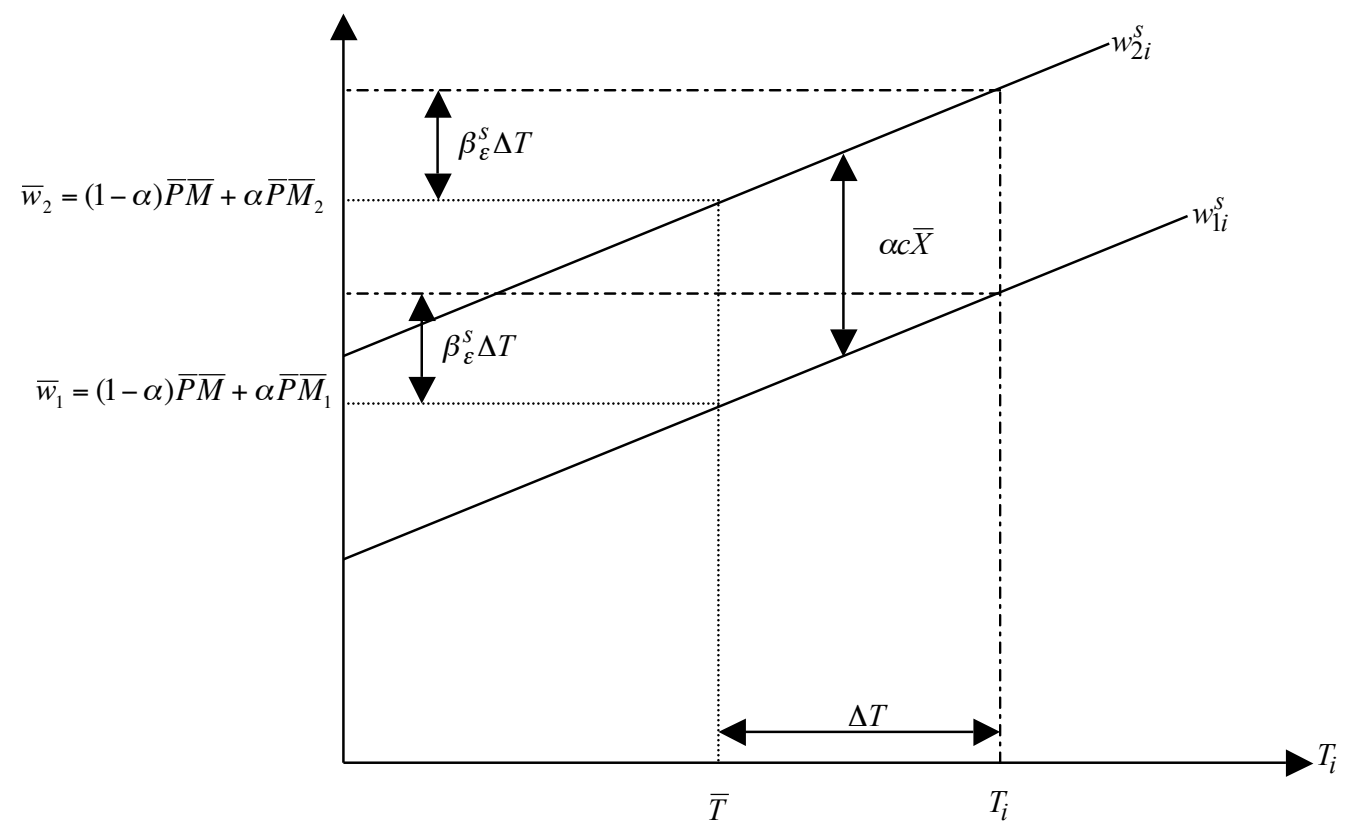

FIGURE 2: EQUILIBRIUM WAGE PROFILES FOR MEN AND WOMEN AT THE TWO

\section{PERIODS}
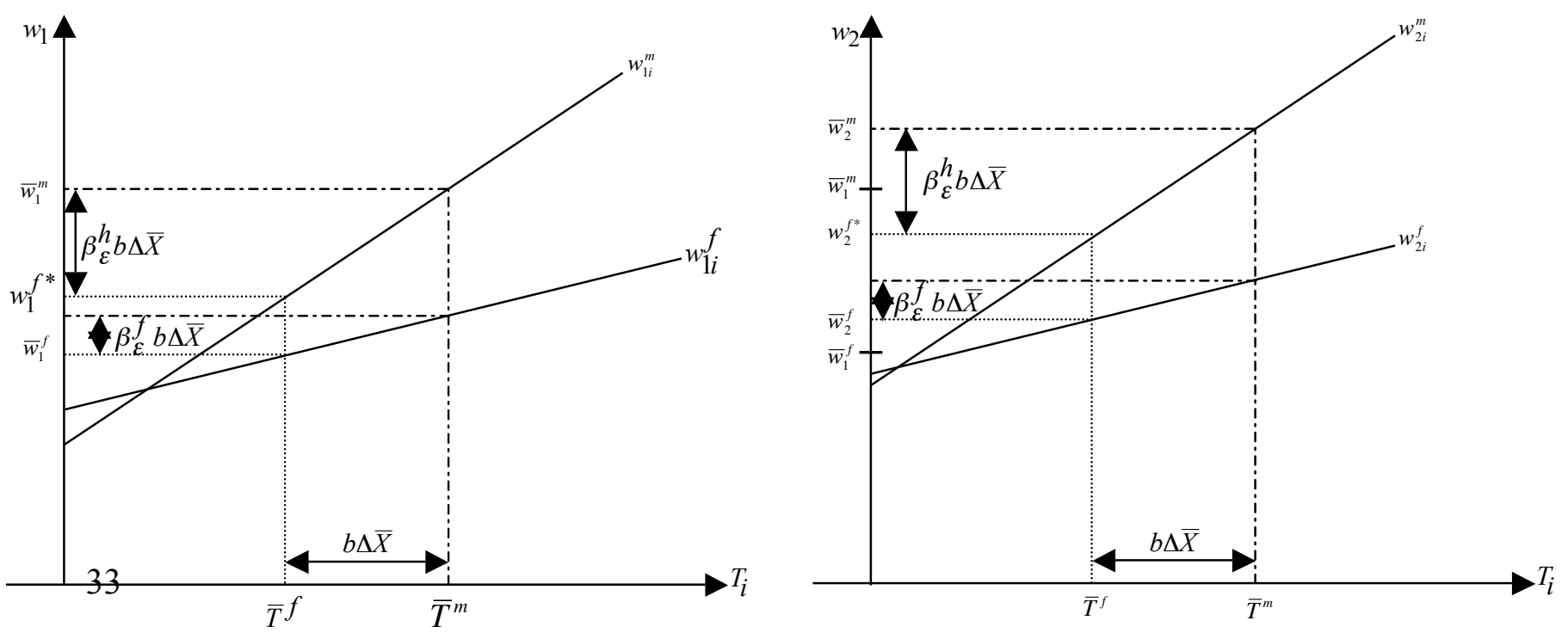